\title{
The Investigation of Students' Attitudes toward Project Work in Enhancing Independent Learning in English I at King Mongkut's University of Technology North Bangkok
}

\author{
Asst. Prof. Raveewan Wanchid Ph.D
}

\section{Karnchanoke Wattanasin Ph.D}

Department of Languages, King Mongkut's University of Technology North Bangkok, Bangkok, Thailand Email: rwanchid@hotmail.com, karnchanok@gmail.com

\author{
Doi:10.5901/mjss.2015.v6n5p581
}

\begin{abstract}
The objectives of the study were: 1) to survey the students' attitudes toward the project work used in the English I course; 2) to compare the attitudes toward the use of project work of high, moderate, and low English proficiency students; 3) to investigate the correlation between the students' attitudes and their English learning achievement. The population was 4,000 first-year students enrolled in English I. The subjects were 360 students from different faculties selected using the stratified random sampling technique. An English achievement test and a close-ended questionnaire were used for the quantitative data collection. The qualitative data were gathered from the open-ended questionnaire and interviews. Descriptive statistics such as mean and Standard Deviation (S.D.), the Pearson correlation coefficient, and one-way ANOVA were used to analyze and explain the data. The results showed that the students had high to moderately positive attitudes toward the use of project work in their English class. Moreover, the results revealed that there was no difference in how the high, moderate, and low proficiency students viewed the project work, and the statistical significance of the correlation between students' attitudes and their final scores was not found. Interestingly, the qualitative data yielded invaluable results that provide useful information for further research and pedagogical implications for language teachers.
\end{abstract}

Keywords: Attitudes toward project work, Different levels of general English proficiency, Independent learning, Project work

\section{Introduction}

Nowadays, technology influences almost every aspect of people's lives, and computer technology has become a common tool for the communication of people in business, education, entertainment, and social life. More importantly, computer technology skills are considered as one of the $21^{\text {st }}$ century skills that students must possess. Likewise, the field of English language learning, therefore, cannot escape the growing impact of computer technology. Nowadays, most classrooms at Thai universities are well equipped with a computer, an overhead projector, a visualizer and Internet accessibility. Further, most Thai university students, especially in Bangkok, have notebook computers, tablets, and smart phones which can connect to the Internet, and they normally bring them to their English language class for looking up vocabulary online and searching for information. The traditional atmosphere, in which students sit quietly, listen to a lecturer, and look at the whiteboard, is a scene from the past that no longer occurs in today's language class. The fact is that we, language teachers, could not separate students' lives from the computer technology, and we as well cannot shy away from the impact of computer technology, which has continuously influenced language education. Consequently, one way to deal with this challenge is to prepare in advance and seek opportunities to integrate computer technology-related tasks in the language class to serve the lifestyles and various learning styles of Generation Y students.

Many research results have shown that Thai learners have lower ability than international students in both subject knowledge and English knowledge (Prapphal, 2003), and the average TOEFL score of Thais ranks next to last in English proficiency in Southeast Asia, above only Cambodians (The Nation, 2005). With the rapid changes of the technology in our highly-competitive world, it seems to be very clear that if the country does not overhaul the teaching of English, the country will lose its competitive edge internationally. Therefore, there is a strong and urgent need to improve the quality of English instruction, and teachers are unavoidably responsible for exploring effective teaching methods and assessments in order to endow students with the skills and knowledge needed to respond to global demands so that they will be capable of competing with others in the highly competitive global marketplace. Although the Ministry of University Affairs of Thailand (2004) has proclaimed the curriculum standard of English language learning for Thai university English courses, which is "to use English to help achieve personal and academic goals and to promote life-long learning," the 
attempts will definitely be useless if the appropriate teaching and learning methodology is not employed.

At King Mongkut's University of Technology North Bangkok, English I is the required course for first year students from different faculties. Each class has 45 to 60 students who have different English language proficiency levels and different learning styles. Due to the large class size and different learning preferences, it is hard for a teacher to pay attention to individual student equally or allow one to practice the English skills sufficiently in a limited class time. To solve this problem successfully, an effective teaching approach assigning students to do meaningful tasks that are beneficial to their future career and that enhance their learning engagement as well as their independent learning skills is required.

To keep pace with the growing impact of computer technology and to equip students with the appropriate life-long learning and professional working skills through English language learning, project work was implemented in this study. Project work refers to a motivated instructional model that engages students in authentic and real-world tasks that can improve their English language ability and independent learning skills (Moss and Van Duzer, 1998). Haines (1989) suggested that the use of project work could be utilized with almost all levels, ages, and abilities of learners, and it can be attached to any syllabus to maximize the learners' ability to learn every subject.

Based on the rationale of the study previously discussed, it was therefore worth the time and effort to apply the project work in the English language classroom and to investigate the students' attitudes toward the use of project work, as it is believed that project work can provide students with opportunities to practice the target language in authentic situations so that they will have more opportunities to use the language needed in real life and become independent learners.

\section{Literature Review}

The Project-based Learning Approach is "an instructional approach that contextualizes learning by presenting learners with problems to solve or products to develop" (Moss and Van Duzer, 1998). According to Thomas (2000), Project-based Learning is defined as a model that organizes learning around projects. The rationale for using project-based learning is the attempt to combine the English learned in the classroom and the authentic language that students encounter in their real life (Fried-Booth, 1997).

Normally, the process of project work is divided into three main phases (Moss and Van Duzer, 1998): 1) selecting topics of interests at the beginning of the class, 2) making plans and doing research, and 3) sharing results with other groups. As projects are complex tasks, to successfully do projects, therefore, demands a number of "soft" skills of the students-starting from researching information, negotiating with their group members, designing the given tasks, making decisions, solving the problems that might occur during the project, and evaluating their performance.

The conceptual underpinning of this teaching method is mainly derived from Vygotsky's Social Constructivism Theory, which strongly suggests that knowledge is constructed from the learners' own experience, current knowledge, and social interaction. Cooperative learning is behind the success of this approach. The main principle of this approach is that the students, in a team, will cooperatively work to complete the tasks and will encourage their teammates to progress and help each other to complete it (Kim, 2001). The cooperation among learners in the learning process has a vital role to play as a motivating factor, resulting in interpersonal relationships and the involvement and development of the individual (Fried-Booth, 1986).

In fact, the project-based learning approach is not new, and it has earned its popularity in English language instruction for decades owing to the considerable benefits revealed from previous studies. For example, through project work the students gain ability to effectively cooperate in a group work, deal with interpersonal conflicts, and figure out solutions for complex problems while working with their group members (Kloppenborg and Baucus, 2004; Bell, 2011). It is believed that these social skills are necessary for working successfully in the $21^{\text {st }}$ century. In this study, the students were assigned to create a 7-10 minutes video project clip using three main themes related to the content they have studied: English in daily life, intercultural communications, and English for tourism.

Regarding the literature on using videos in English language instruction, Greene and Crespi (2012) investigated the perceived value of college student-created videos as a tool for enhancing the student's learning experience. Creating videos is required in marketing courses, for example, while this task is an optional extra credit assignment in the accounting class. The results revealed that students in both business courses appreciated the video experience, as they thought that the task was relevant and entertaining. They agreed that it helped to reinforce the concepts they were exposed to in class. Additionally, other advantages that may not occur in a typical classroom are that the video project requires more preparation time and effort on the part of the students, and the process of creating course content videos will produce a richer understanding of the subject matter for students as they have to write a script, read it, recite it, create a video, and edit it. These steps then repeatedly expose and reinforce the subject content for the students. Importantly 
enough, the video project also encourages students to be active learners compared to the traditional lecture classroom. The project provides the students with a greater degree of satisfaction with the course, subject content, instructors, and classmates. Other benefits of using a video-created project are that it increases student motivation (Ryan, 2002; Hoffenberg and Handler, 2001), supports an authentic learning environment (Kearney and Schuck, 2003), encourages student engagement (Schuck and Kearney, 2004), supports student creativity (New, 2006; Parker, 2002), and accommodates students with different learning styles and abilities (Sage, 1996).

However, it is worth noting that most of the findings regarding the benefits of student-created videos are the opinions of educators and students at the secondary or elementary school level. The research literature on the subject of student-created videos is for this reason limited and should be explored at the college level (Hofer and Swan, 2005). As a result, this study will fill this gap by investigating university students' attitudes toward the use of a video project in an English I course as well as the relationship between their attitudes and final scores.

\section{Research Objectives}

1. To survey the students' attitudes toward the project work used in the English I course

2. To compare the attitudes of high, moderate, and low English proficiency students toward the project work used in the English I course

3. To investigate the correlation between the students' attitudes and final scores

\section{Research Questions}

1. What are the students' attitudes toward the project work used in the English I course?

2. Is there any significant difference among the high, moderate, and low proficiency students toward the project work?

3. Is there any correlation between the students' attitudes and final scores?

\section{Research Hypotheses}

1. There is no significant difference among the attitudes of the high, moderate, or low proficiency students toward project work.

2. There is a positive correlation between the students' attitudes and final scores.

\section{Methodology}

This study is a survey research design that aimed at investigating the students' attitudes toward the use of project work in English I course, and it is considered as correlational study as well since the relationship between the students' attitudes and the students' final scores were also explored.

\subsection{Subjects}

The population was 4,000 Thai first-year undergraduate students who enrolled in English I as a requisite course at KMUTNB in the first semester of academic year 2012. The samples of this study were 360 students who were randomly selected from the population. The samples were sufficient for the study as Krejcie and Morgan (1970) stated that a sufficient sample size with a reliability of $95 \%$ and errors of not more than $5 \%$ out of 4,000 , the number of population should be about 360 . The majority of the student participants taking the questionnaire were male $(53.61 \%)$, and their average age was 18.33 years of age. At the time of the data collection, the participants were currently enrolled in the Faculties of Engineering (37.22\%), Applied Science (32.5\%), and Technical Education (30.28\%).

\subsection{Instruments and Data Collection}

The following instruments were used to collect the data in this study: 


\subsubsection{Attitude Questionnaire}

The survey for the study was carried out at the end of the experiment. The designed questionnaires were administered to the subjects - 360 KMUTNB first year students participating in the study. The questionnaire is composed of three main parts: attitudes toward project work, attitudes toward autonomy, attitudes toward teamwork, and attitudes toward dependence on the teachers. The questionnaire was validated by the three experts and piloted before the main use. In order to reach the same understanding, the questionnaires were translated into Thai before being administered with the students. The students were asked to rate the degree of agreement on each item, the rating criteria are a five point Likert scales:

$$
\begin{aligned}
& 5=\text { Strongly Agree } \\
& 4=\text { Agree } \\
& 3=\text { Neutral } \\
& 2=\text { Disagree } \\
& 1=\text { Strongly Disagree }
\end{aligned}
$$

The evaluation criteria of the questionnaire are as follows:

\begin{tabular}{ll}
\hline $1.00-1.50$ & The positive attitude towards the project-based learning approach is very low. \\
1.51-2.50 & The positive attitude towards the project-based learning approach is low. \\
2.51-3.50 & The positive attitude towards the project-based learning approach is moderate. \\
3.51-4.50 & The positive attitude towards the project-based learning approach is high. \\
4.51-5.00 & The positive attitude towards the project-based learning approach is very high. \\
\hline
\end{tabular}

\section{2 .2 Interview}

In order to gain more in-depth data, the interviews were conducted at the end of the course, out of class, and taperecorded. After the English 1 course was completed and grades were announced, thirty students-10 receiving grades A to $B, 10$ receiving grades $C+$ and $C$, and 10 receiving $D+$ to $F$-were interviewed. The interview sessions, each of which lasting approximately 15 to 20 minutes, were semi-structured and employed for the purpose of triangulating with the results of the questionnaire. All of the interviews were conducted in Thai, the student participants' native language, in order to prevent language difficulty and anxiety, which could lead to the participants being unable to respond truthfully. Three questions similar to those in the questionnaire's open-ended section were asked: (1) What are your thoughts and feelings in general toward doing the video project for English 1?; (2) What were the problems found while doing the video project?; and (3) Do you have any other comments about studying English 1 for the improvement of the course in later semesters?

\subsection{The Experimental Process}

The following table illustrates the experimental process in the study.

Table 1: The Experimental Process

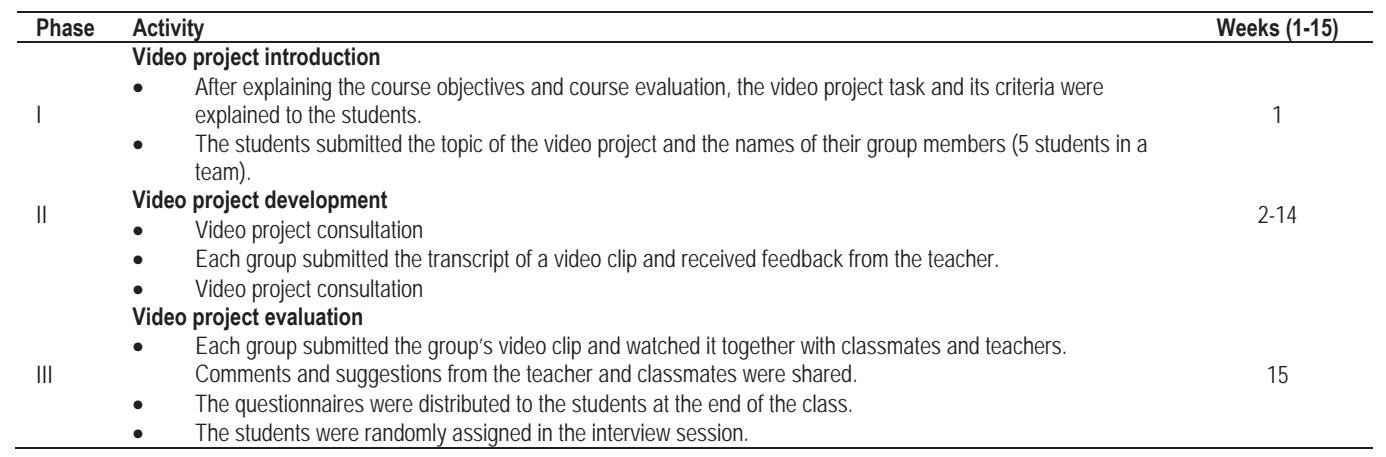




\subsubsection{English I Course}

The objectives of the course were as follows: 1) to communicate in functional ways, using spoken and written English; 2) to use vocabulary learned from the textbook and other materials supplemented for the course; 3 ) to write sentences and short paragraphs; and 4) to make good use of materials in the SALC to promote lifelong learning. The class duration was 3 hours per week, and it lasted for 15 weeks. The coursebook used in this course was Global written by Clandfield (2010), Macmillan publisher.

\subsubsection{The Development of the Project Work}

Students formed groups of 5 and created a video clip of themselves speaking English using conversation topics related to the coursebook, which are English in daily life, intercultural communications, and English for tourism.

1. The conversation(s) could be an adaptation of any listening script(s) in the book, an adaptation of conversations acquired outside the textbook, or conversation(s) created by the students themselves.

2. The video must be 7 to 10 minutes long, consisting of all students in the group talking in English.

3. It was noted that all video clips would be eligible for a competition at the end of the semester, and the awarded winners' videos would be on display at the Self-Access Learning Center (SALC), KMUTNB as well as English Fun Fair, an annual project of the Department of Languages, Faculty of Applied Arts.

4. Regarding the video project scoring, the total score for this project was 10 points. It was divided into three parts:

Part 1: Topic submission (Week 6) = 1 point. If students submitted the topic on time, they would receive 1 point.

Part 2: Script submission (Week 11) 4 points. Points would be given according to the following criteria:

1. Students listed the responsibilities of each group member. (1 point)

2. Students provided a list of steps in doing the project. (1 point)

3. Students listed the tools and materials used. (1 point)

4. Students provided video scripts with references. (1 point)

Part 3: Video clip submission (Week 15) = 5 points. The following criterion was used to assess the video clip.

\begin{tabular}{|l|c|c|c|}
\hline Items & \multicolumn{3}{|c|}{ Points $^{\star}$} \\
\hline Creativity & 3 & 2 & 1 \\
\hline Language use & 3 & 2 & 1 \\
\hline Organization & 3 & 2 & 1 \\
\hline Integration of textbook content & 3 & 2 & 1 \\
\hline Technology & 3 & 2 & 1 \\
\hline
\end{tabular}

*Points: 3 = Excellent, 2 = Good, 1 = Fair

\subsubsection{A Teacher's Role}

It is noted that the teacher played a role as a facilitator and consultant who helped the students to learn and facilitated active interaction between learners during the project work development.

\subsubsection{A Student's Role}

The student-centered approach is the conceptual underpinning of the English I course, so the students in this course played a role as active learners who controlled their own learning through their video project development. They were writers, readers, actors, producers, commentators, and assessors as well.

\section{Results of the Study}

\subsection{Research Question 1}

What are the students' attitudes toward the project work used in English I course? 


\subsubsection{Attitude toward project work}

There were sixteen items in the questionnaire dedicated to student attitude toward the benefits of project work, as can be seen in Table 1. Out of these sixteen items, fifteen received high average scores from 3.56 to 4.12, and one item received an average of 3.48 , a moderate attitude score. All in all, the student participants' answers showed that the project work enabled them to use their creativity, helped make them feel more confident and relaxed, that project work made English more interesting, improved their computer skills and the four English skills, and that the students agreed that project work should be a part of the English course in which they were enrolled. The results appear to collaborate the interviews showing that most of the students enjoyed doing the video project as it involved the use of technology, as was depicted in the following statement.

"[The video project] was good. It was like what I did for my English course in high-school, which I did well. I like using video-making programs in my computer. It was fun making the video to look cool".

Besides, most of the interviewees realized the role that the video project played in improving their English, it was a fun activity because it allowed them to work outside the classroom, and some voiced their preference of the video project over taking tests.

Table 1: Questionnaire items on student attitude toward project work

\begin{tabular}{|c|l|c|c|c|}
\hline Item & Statement & Mean & S.D. & Moderate \\
\hline 1 & The video project made me use my creativity. & 4.12 & 0.71 & High \\
\hline 2 & The video project for English 1 was useful. & 4.05 & 0.79 & High \\
\hline 3 & I am willing to let the video project's score be one of the criteria for English 1 evaluation. & 4.00 & 0.92 & High \\
\hline 4 & The video project made me participate in class more. & 3.96 & 0.74 & High \\
\hline 5 & The video project made me feel braver to open up. & 3.95 & 0.76 & High \\
\hline 6 & The video project made me improve my computer skill. & 3.88 & 0.85 & High \\
\hline 7 & The video project made me improve my reading skill. & 3.85 & 0.72 & High \\
\hline 8 & The video project made me improve my speaking skill. & 3.83 & 0.70 & High \\
\hline 9 & The video project made studying English more interesting. & 3.81 & 0.72 & High \\
\hline 10 & I support the use of video project for English 1. & 3.76 & 0.87 & High \\
\hline 11 & The video project made me improve my listening skill. & 3.74 & 0.73 & High \\
\hline 12 & Using the video project is an appropriate means of studying. & 3.71 & 0.72 & High \\
\hline 13 & The video project made me become more confident in speaking English. & 3.68 & 0.79 & High \\
\hline 14 & The video project made me improve my writing skill. & 3.64 & 0.75 & High \\
\hline 15 & $\begin{array}{l}\text { More projects should be assigned for the students to do when studying English so that the scores } \\
\text { allocated for the midterm and final examinations will be reduced. }\end{array}$ & 3.56 & 1.14 & High \\
\hline 16 & The video project made me feel more relaxed than when I study in the classroom. & 3.48 & 0.90 & Moderate \\
\hline
\end{tabular}

\subsubsection{Student autonomy and teamwork}

Student autonomy and working with teammates are two important aspects of the learner-centered approach. In the questionnaire employed for the present research, there were 13 items dedicated for autonomy and 8 items for teamwork. Their average scores are reported in Tables 2 and 3.

Table 2: Questionnaire items on student autonomy

\begin{tabular}{|c|l|c|c|c|}
\hline Item & Statement & Mean & S.D. & Meaning \\
\hline 1 & The video project made me look for more knowledge outside the classroom. & 4.13 & 0.79 & High \\
\hline 2 & The video project helped me to gain knowledge in addition to what I learned in the classroom. & 3.97 & 0.75 & High \\
\hline 3 & The video project helped me develop learning autonomy. & 3.94 & 0.79 & High \\
\hline 4 & The video project made me become more responsible for studying. & 3.88 & 0.77 & High \\
\hline 5 & I applied the knowledge from the classroom when I did the video project. & 3.86 & 0.72 & High \\
\hline 6 & I tried to search for what I wanted to know by myself while working on the video project. & 3.65 & 0.70 & High \\
\hline 7 & I can determine my strengths and weaknesses in studying English by looking at my video project. & 3.60 & 0.79 & High \\
\hline 8 & I can determine the level of my own English proficiency by looking at my video project. & 3.58 & 0.81 & High \\
\hline 9 & After completing the video project, I am confident that I can study efficiently outside classroom all by myself. & 3.45 & 0.73 & Moderate \\
\hline
\end{tabular}


\begin{tabular}{|l|l}
\hline 10 & I did not need any help from the teacher when working on the video project.
\end{tabular} $2.310 .95 \mid$ Moderate

11 I think the teacher's advice on the video project was necessary.

12 When there was a problem while doing the video project, I made my teacher solve the problem for me. 4.11 0.76 $\quad$ High

13 I needed more help from the teacher.

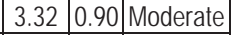

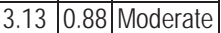

Thirteen items were dedicated to student autonomy in the questionnaire. The items were divided into issues concerning independent learning outside the classroom (Items 1, 2, 3, 4, and 6), applying knowledge from classroom (Item 5), increasing student motivation (9), and developing students' English (Items 7 and 8). With the exception of the average scores for Items 10 to 13, which are related to student dependence on their teachers, those of all the other items pertaining to autonomy were high, ranging from 3.45 to 4.13 , indicating that the video project had helped in the aforementioned aspects.

If student autonomy is one side of a coin, student dependence on their teachers can be compared to the other side. There were four questionnaire items concerning the students' dependence on teachers (items 10-13). Item 11 reflects the opinion of the student participants about the importance of their teachers' advice, and received a high score of 4.11. The other three items reflected the students' actual need of their teachers' help, and their average scores were moderate, ranging from 2.31 to 3.32 .

In Table 3, the means for the eight items in the questionnaire were high (from 3.62 to 4.25), reflecting the student participants' awareness of the importance of the ability to work with others as a team. The aspects about teamwork sprung from cooperating for a video project included working with others (Items 1 and 2), developing self-confidence (Items 4 and 5), knowledge sharing (Item 3), making a decision (Item 6), solving a problem (Item 7) and evaluating oneself after receiving feedback from others (Items 8). However, some problems stated in the interview results were that some of their friends offered little help on the project.

Table 3: Questionnaire items on teamwork

\begin{tabular}{|c|l|c|c|c|}
\hline Item & Statement & Mean & S.D. & Meaning \\
\hline 1 & The video project allowed me to work with others as a team. & 4.25 & 0.71 & High \\
\hline 2 & The video project increased the skill of cooperating with others. & 4.12 & 0.68 & High \\
\hline 3 & The video project encouraged me to exchange knowledge with my friends. & 4.04 & 0.68 & High \\
\hline 4 & The video project made me become braver to say what I think. & 3.86 & 0.71 & High \\
\hline 5 & The video project enabled me to interact more with my friends outside of class. & 3.81 & 0.88 & High \\
\hline 6 & I like the fact that my classmates and I could make the decision on how to do the video project. & 3.79 & 0.77 & High \\
\hline 7 & When there was a problem while doing the video project, my friends and I could solve it by ourselves. & 3.78 & 0.72 & High \\
\hline 8 & I learned about my English ability from my friends' suggestions while doing the video project. & 3.62 & 0.69 & High \\
\hline
\end{tabular}

\subsection{Research Question 2: Is there any significant difference among the attitudes toward the project work of the three} groups of the students (High/Moderate/and Low proficiency)?

The student participants were divided into three groups according to their total raw scores: high, average, and low English proficiency groups categorized by using percentile rank. The three groups of students were compared using the one-way ANOVA analysis, as shown in Table 4. In addition, a multiple comparison analysis was conducted with Tukey and Scheffe tests to confirm the results. It was found that the attitudes of the student participants across the three groups of English proficiency did not have statistically significant difference. In other words, there is no difference in how the students of high, average, and low proficiency viewed the video project-which confirms the present study's hypothesis proposed earlier.

Table 4: One-way ANOVA results comparing the attitudes of students from three levels of proficiency

\begin{tabular}{|l|c|c|c|c|c|}
\hline & Sum of Squares & $\mathrm{df}$ & Mean Square & $\mathrm{F}$ & Sig. \\
\hline Between Groups & .083 & 2 & .042 & .448 & .639 \\
Within Groups & 33.228 & 357 & .093 & & \\
Total & 33.312 & 359 & & & \\
\hline
\end{tabular}




\subsection{Research Question 3: Is there any correlation between students' attitudes and final scores?}

According to Table 5, the result showed that the statistical significance of the correlation between students' attitudes and their final scores was not found. ( $r=-.053, p>0.05)$ although the negative relationship was obtained.

Table 5: Pearson Correlation between Students' attitudes and the final scores

\begin{tabular}{|ll|c|c|}
\hline \multicolumn{2}{|c|}{ Correlations } \\
\hline \multirow{3}{*}{ Attitudes } & Pearson Correlation & Attitudes & Final scores \\
& Sig. (2-tailed) & 1 & -.053 \\
& $\mathrm{~N}$ & & .319 \\
\hline \multirow{3}{*}{ Final scores } & Pearson Correlation & -.053 & 360 \\
& Sig. (2-tailed) & .319 & 1 \\
& $\mathrm{~N}$ & 360 & 360 \\
\hline
\end{tabular}

From the questionnaire results, it can be summarized that the students tended to have positive attitudes toward the use of project work in English I course. Moreover, there was no significant difference of the attitudes of the students from the high, moderate, and low proficiency groups. As a result, it is no doubt why the statistically significant result of the correlation between the students' attitudes and the final scores was not found.

\section{Discussion}

\subsection{The students' attitude toward the video project}

\subsubsection{Positive attitudes}

At institutions in Thailand where students major in science and technology, it is commonly known that English can be viewed as secondary. Some students attend their English classes merely for the reason that the courses are required. It has been, therefore, many educators' goals to find ways that help draw the students' interest so that they can learn English for their future success. Fortunately, employing video projects as one of the criteria in an English course may be a wise alternative, as the results from the questionnaire, which was supported by those from the interviews, indicated that on average, the student participants enjoyed doing the video project. The benefits stated by the students were that the video project was useful, allowed them to use their creativity, involved the use of technology, enabled them to work with friends, and encouraged them to use and practice English more.

Generally speaking, students are aware that English is useful, the fact with which they may or may not personally agree. Even though students realize the benefit of the video project, as seen in their responses in the questionnaire as well as from the interview sessions, the statements and a high average score from the questionnaire do not suffice, as it can be argued that the student participants at the time of the responses were well aware that the project must be useful. This awareness may be due to the highly encouraged knowledge of English expressed among parents and teachers, thus, indicating the students' thoughts and beliefs rather than their emotional reaction to the project itself (Gardner and Lambert, 1972). It is important, therefore, to scrutinize further what the students associated with their positive attitudes as they answered the questions for this research, which will in turn lead to our knowledge of important factors to students' learning motivation.

\subsubsection{Autonomy and teamwork}

The video project fostered students' ability to look for more knowledge and improve their English outside the classroom on their own time. This benefit of the video project stated by the students both in the questionnaire responses and interviews corresponds with the benefit of project work in general (Holec, 1987). As the students were compelled to complete their project work, they became more independent and had to initiate activities by themselves outside the classroom. In other words, doing project work allowed the students to be more independent and in control. In addition to enabling them to be immersed in English to a greater degree, the project raised the students' confidence in using the 
language.

The traditional Thai classrooms place an emphasis on teachers as authority and knowledge givers. As a result, students in such classrooms rely on their teachers to plan for activities, explain or prescribe materials, find resources, and solve problems. However, students in the modern world are exposed to values from the more modern countries, and seem to welcome the ability to be more independent, which project work provides. When students are assigned project work to be completed on their own time and outside the classroom context, they are also given more freedom to create, improvise, and have a sense of ownership that traditional teacher-based classrooms do not have. As autonomy received the highest score in the questionnaire for this study, being autonomous may be the most important reason for the participants' positive attitudes toward doing project work. This observation indicates that any classroom activity or assignment that incorporates autonomy may be highly welcome by students nowadays.

However, independence does not necessarily mean individual work. From the questionnaire and interview responses, working with others appeared to be another important issue pertaining to the video project for the students joining this research study. The students pointed out many benefits of teamwork: cooperating with friends, sharing what they knew and learning from them. As they work on the project, students are empowered as well as challenged to express, negotiate, and learn with their teammates. At the same time, they develop a sense of belonging in a team that can help each other select a topic and work toward accomplishing their mutual goal. As teens naturally feel comfortable with approval, reassurance, and solidarity, it can be argued that a sense of belonging in a group whose members support one another helped the student participants to enjoy doing project work more when compared to working in such an isolated environment as studying in a classroom.

Unfortunately, teamwork not only led to work improvement and self-development, it also caused a number of constraints to the completion of the project. In other words, working with others to these students involved having the same free time period to work together as well as the willingness to cooperate from all team members. When some members did not cooperate-when there was only one member with video editing ability and he/she did not finish the work in time, for example-working in a team caused them a great amount of stress.

Even though the students had relatively high positive attitudes toward the video project, such stress on working and completing the project expressed by the students in the open-ended section of the questionnaire as well as in the interviews should be taken into consideration. It is ironic that the very things that contribute to the fun of project work are the same things that caused them constraints and, in turn, stress. As mentioned above, working as a team required similar classroom and free-time schedules and the ability to carry out one's responsibility. In the present study, students in one class could come from different majors, hence, the discrepancy in the time they could work together. Unlike the students in the studies by Sudrung (2004) and Naknoi (2007), most of the students in the present research were only beginning to know one another during that semester, making it more difficult to negotiate issues with group members when facing such problems and those concerning meeting deadlines. In addition, technology was also repeatedly viewed by the students as problematic, since not all of the students were good at using their computers to make videos. Some instructors asked their students to add English caption to their videos, making it more difficult for those without adequate skills to complete the task. It can be argued, for this reason, that careful planning with regard to group members and students' abilities, or lack thereof, is a vital factor in enabling project work to help students to learn more autonomously, make good use of peer feedback and cooperation, and create more knowledge on their own (Rosen, 1998).

\subsubsection{No attitude difference across proficiency levels or course final scores}

The results of this study revealed that there was no statistically significant difference among the attitudes toward the video project of students from three levels of proficiency: high, moderate, and low. In the same vein, there was no significant correlation between attitudes and the students' final scores. The data from the interview section were constituted by reports of a variety of problems. Even though their language ability, in this case specifically writing the scripts in English, was reported to thwart their ability to complete the project, it was not the only obstacle, since students from all levels also those caused by technology, time conflicts, and teamwork problems. As discussed by Gardner and Lambert (1972), even though attitude and motivation play a crucial role in language learning, aptitude does not directly correlate with attitude. In other words, attitude, motivation, and such other factors as self-efficacy and aptitude may play important roles in students' learning, yet there can be other factors affecting the attitudes of these students. As discussed earlier regarding constraints on the success of project work, apart from their English proficiency, the social contexts the students were in-how much they knew one another and how well they were able to use technology to complete the task-should not be ignored.

Another interesting result from the data analyses is the students' need for their teachers' guidance and assistance. 
No matter how enabling project work is, students cannot become independent overnight (Dickinson, 1987; Swatevacharkul, 2006; 2009), and the concerns voiced by student participants in this study revealed that teachers' help is still greatly needed. This need for teachers' guidance may be especially true in the Thai context where teachers are traditionally viewed as the only authority in the classroom from whom all decisions and judgment come-an attitude shared both by students and teachers. As a result, implementing project work takes more than students' attitudes; the teachers themselves need to understand their roles and, as suggested by Kraft (2005), assist their students as facilitators instead of as the authority and the source of knowledge (Donnelly and Fitzmaurice, 2005).

\section{Summary}

In summary, we could not deny the fact that the students' learning behaviors have been dramatically changed as the arrival of the computer technology; they can learn the English language through various sources from the Internet such as websites or YouTube. As a result, the English language course will definitely be viewed as an "old hat" which is boring and demotivating for students if the tasks are not meaningful, do not match their leaning styles, or cannot serve today's needs of the students. In this research, the students had highly positive attitudes toward project work in the English course as it offers considerable benefits to the students especially in terms of teamwork and learning autonomy. Besides, there is no difference in how the students of high, average, and low proficiency viewed the video project, since this method can work with all levels of students. Therefore, it is not surprising why the correlation between students' attitudes and the final scores are not shown.

\section{Pedagogical Implications}

In doing project work, the students improve the English language skills, learn to work in a team, and gain how to learn by themselves out of class with less assistance from the teachers. However, even though some computer technology knowledge and skills for creating a video project is considered the twenty-first century's required skills of the students, some teachers may feel anxious and uncomfortable when implementing this technological related task in their classes, since they may have limited computer technology skills. As students' lives and communication technology cannot be separable in the future, teachers should be trained in how to use the computer technology in EFL instruction. Although computer technology cannot substitute good language teachers, it is necessary for EFL teachers to gain this knowledge to make their English language course more effective.

\section{Recommendations for Further Research}

1. This research study has shown that employing project work in the English classroom helps students in various aspects. Researchers and practitioners should continue to investigate this topic in order to help students learn English more efficiently. Since teacher-centered classrooms conflict with the modern world where students should be encouraged to look for more knowledge on their own with teachers functioning as facilitators rather than authority figures, research on project work should focus to a greater degree on how to make the most of this type of course assignment by finding ways to facilitate student autonomy as much as, in the foreign language context where teachers usually assume great importance in the classroom such as Thailand, searching for ways to reduce that traditional role of the teachers.

2. Further research studies would benefit greatly from the investigations of how much students plan, implement their plan, and solve problems while working on their project work compared to their level of dependence upon the teachers. The differences, or similarities, between project work with different requirements, for example, students having to have a conversation with native English speakers or merely recite a pre-scripted conversation, should be studied to better our understanding about how authentic use of English influences students' language learning.

3. Furthermore, the roles of teachers in project work are very crucial for the success of not only the students' work outcome but also how much students are guided so that they learn by themselves (Donnelly and Fitzmaurice, 2005). Research in which different generations of teachers participate can be carried out focusing on the teachers' understanding of how to facilitate project work, the awareness of their roles in and outside the classroom, and the role they take in their own classrooms. 


\section{Acknowledgements}

Without the financial funding granted by the Faculty of Applied Arts, King Mongkut's University of Technology North Bangkok, this research would not have been successfully conducted.

\section{References}

Bell, L. (2001). Preparing tomorrow's teachers to use technology: Perspectives of the leaders of twelve national education associations. Contemporary Issues in Technology and Teacher Education, 1 (4), pp. 517-534.

Clandfield, D. (2010). Global (Pre-intermediate). Oxford. Macmillan publisher.

Dickinson, L. (1987). Self-instruction in language learning. Cambridge: Cambridge University Press.

Donnelly, R., and Fritzmaurice, M. (2005). Collaborative project-based learning and problem-based learning in higher education: A consideration of learner-focused strategies. In G.

O'Neill, S. Moore \& B. McMullin (Eds.) Emerging Issues in the Practice of University Learning and Teaching, Dublin: AISHE/HEA, 87-98.

Fried-Booth, D.L. (1986). Project work. New York: Oxford University Press.

Fried-Booth, D. L. (1997). (8th Ed.). Project work. New York: Oxford University Press.

Gardner, R. C., and Lambert, W. E. (1972). Attitudes and motivation in second language learning. Rowley: Newbury House.

Greene, H., and Crespi, C. (2012). The value of student created videos in the college Classroom: An exploratory study in marketing and accounting. International Journal of Arts and Sciences, 273-283.

Haines, S. (1989). Projects for the ELF classroom: Resource material for teachers. Walton-on-Thames Surrey, UK: Nelson.

Hofer, M., and Owings Swan, K. (2005). Digital moviemaking-the harmonization of technology, pedagogy and content. International Journal of Technology in Teaching and Learning, 1(2), 102-110.

Hoffenberg, H., and Handler, M. (2001). Digital video goes to school. Learning and Leading with Technology, 29(2), 10-15.

Holec, H. (1987). The learner as manager: Managing learning or managing to learn? In A.L. Wenden, and J.Rubin (eds). Learner Strategies for Language, Cambridge: Prentice-Hall, 145-156.

Kearney, M., and Schuck, S. (2003). Authentic learning through the use of digital video. In W. Au and B. White (Eds.) Proceedings of the Australian Computers in Education Conference. [CD-ROM].

Kim, B. (2001). Social Constructivism. In M. Orey (ed.). Emerging Perspectives on Learning, Teaching, and Technology. Retrieved December 6, 2005, from: http://www.coe.uga.edu/epltt/SocialConstrctivism.htm.

Kloppenborg, T. J., and Baucus, M. S. (2004). Project management in local nonprofit organizations: Engaging students in problem-based learning. Journal of Management Education, 28, 610-630.

Kraft , N. (2005). Criteria for Authentic Project-Based Learning. RMC Research Corporation Denver, Colorado. Retrieved January 9 , 2010, from http://www.rmcdenver.com/useguide/pbl.htm

Krejcie, R.V., \& Morgan, D.W. (1970). Determining sample size for research activities. Educational and Psychological Measurement, 30, 607-610.

Moss, D., and Van-Duzer, C. (1998). Project-based Learning for Adult. ERIC Digest: English Language Learners. 1998: 12-20.

Naknoi, K. (2007). A Study of the Effect of Project Work Learning on Mattayomsuksa 2 Students' Ability in Using English for Communication at Srinagrarindra the Princess Mother School Kamphaengphet. Master Thesis, M.A. (Teaching English as a Foreign Language). Bangkok: Graduate School, Srinakharinwirot University.

New, J. (2006). Film school: The silver screen inspires young minds to think big.

Edutopia, 1(9), 2023. Retrieved January 8, 2014, from: http://www.edutopia.org/film- school.

Office of the Education Council, Ministry of Education, Kingdom of Thailand. (2004). Education in Thailand 2004. Bangkok: Amarin Printing and Publishing.

Parker, D. (2002). Show us a story: An overview of recent research and resource development work at the British Film Institute. English in Education, 36(1), 3844.

Prapphal, K. (2003). English proficiency of Thai learners and directions of English teaching and learning in Thailand. Journal of English Studies, 1(1), 6-12.

Richards, C.J. (2002). The language teaching matrix. USA. Cambridge University Press.

Rosen, D. (1998). Inquiry projects. Retrieved February 17, 2014, from http://www2.wgbh.org/mbcweis/tc/alri/l.M.html

Ryan, S. (2002). Digital video: Using technology to improve learner motivation. Modern English Teacher, 11(2), 72-75.

Sage, S. M. (1996). A qualitative examination of problem-based learning at the K-8 level: Preliminary findings. Paper presented at the Annual Meeting of the American Educational Research Association, New York.

Schuck, S., and Kearney, M. (2004). Students in the director's seat: Teaching and learning across the school curriculum with studentgenerated video (Research Report). Retrieved March 26, 2013, from http://epress.lib.uts.edu.au/research/bitstream/handle/1 0453/14209/SchuckKearney.04.pdf?sequence=1.

Sudrung, J. (2004). A development of the project-based process curriculum to enhance English language skills for upper secondary school students. Master thesis. Education, Chulalongkorn University.

Swatevacharkul, R. (2006). The effects of degrees of learner independence through web-based instruction and levels of general English proficiency on English reading comprehension ability of second year undergraduate learners. Doctoral Dissertation, English as an International Language, Chulalongkorn University. 
Swatevacharkul, R. (2009). An Investigation on readiness for learner autonomy, approaches to learning of tertiary students and the roles of English language teachers in enhancing learner autonomy in higher education. Unpublished research report. Bangkok: Dhurakij Pundit University.

The Nation Editorial. (2005). Better English teaching needed. The Nation.

Retrieved May 8, 2014, from http://www.nationmultimedia.com/search/page.arcview.php?clid=11\&id=119609\&usrsess=

Thomas, J. (2000). A review of research on project-based learning. Retrieved December 6, 2014, from http://www.bie.org/research/ study/review_of_project_based_learning_2000

Thomas, J.W. (1998). Project based learning overview. Novato, CA: Buck Institute for Education. Retrieved July 10, 2002, from http: //www.bie.org /pbl /overview /index.html 